\title{
A New Model of Global Postischemic Reperfusion in Rabbit
}

\author{
Y-J. YANG, ${ }^{*}, 1$ W-X. TANG, ${ }^{2}$ H-C. TIAN, ${ }^{3}$ AND P-L. YU ${ }^{1}$ \\ 'Pediatrics Research Laboratory of First Affiliated Hospital, \\ Hunan Medical University, Changsha, Hunan, 410008, \\ People's Republic of China; 'Department of Electron Microscopy, \\ Hunan Medical University; ${ }^{3}$ Department of Pathophysiology, \\ Bengbu Medical College
}

Received January 30, 1990; Accepted October 19, 1990

\section{ABSTRACT}

An ideal model of global ischemia in rabbits has not yet been developed. The present study describes a new model of global postischemic reperfusion (GPIR) in the rabbit, characterized by lack of systemic hypotension. The experimental procedure involves reversible occlusion of the bilateral internal carotid arteries (ICA) and bilateral external carotid arteries (ECA) for $60 \mathrm{~min}$ combined with permanent ligation of bilateral vertebral arteries (VA). This grouping is called 6-artery occlusion (6AO). Sixty minutes after the occlusion, bilateral ICA and bilateral ECA were released for $120 \mathrm{~min}$ at which time the experiment was terminated. The results revealed severely depressed EEG activity; Water content of brain tissue increased to $80.33 \pm 1.20 \%$ (control $78.28 \pm 0.59 \%, p<0.01$ ) $\mathrm{K}, \mathrm{Mg}$, and $\mathrm{Zn}$ decreased $(p<0.05$ or $p<0.01)$, and were negatively correlated with tissue water content. Na increased $(p<0.05)$ and correlated with water content of brain. No significant changes were observed in lipid peroxide (LPO) levels, but the activity of superoxide dismutase (SOD) of brain tissue decreased $(p<0.01)$, and was negatively correlated with water content $(r=-0.5808, p<0.05)$. These results were compared with those obtained with the model of 4-artery (bilateral common carotid arteries (CCA) and VA) occlusion (4AO) and sug-

${ }^{*}$ Author to whom all correspondence and reprint requests should be addressed. 
gested that the brain damage be more severe with $6 \mathrm{AO}$ than with $4 \mathrm{AO}$.

Index Entries: Global ischemia; 4-artery occlusion; 6-artery occlusion; reperfusion; rabbit.

\section{INTRODUCTION}

A satisfactory model of global postischemic reperfusion (GPIR) should be: (a) ability to induce a condition of severe cerebral ischemia, (b) simple and reliable reproduction, (c) the model uncomplicated by systemic hypotension, and (d) acceptable animal species with respect to size, ease of supply, and without excessive costs. Although many models of global cerebral ischemia have been reported in gerbils (Yoshida et al., 1980), rats (Pulsinelli and Brierley, 1979; Todd et al., 1986), cats (Paschen et al., 1983), dogs (Jackson and Dole, 1979), and the primates (Branston et al., 1980), we consider that the rabbit should be chosen as the best candidate for the model of CPIR because the pattern of brain vessels in the rabbit is more similar to that in the primates and man than that in dogs and cats (Aguilar, 1963; Gu, 1983). In addition, the rabbit's size is bigger than rats, so it is easier to measure intracranial pressure, blood pressure, and to take more blood samples. Moreover, the cost of rabbits is cheaper and they are more easily supplied than dogs, cats, and the primates. Unfortunately, an ideal model of CPIR in the rabbit has not yet been developed. Those models that had been reported usually involved 4-artery occlusion, bilateral common carotid arteries (CCA) and bilateral vertebral arteries (VA) occlusion (i.e., 4AO), and had to drop simultaneously the systemic blood pressure induced either by bleeding (Li et al., 1987) or by drugs (Kolata, 1979; Mchedlishvilli et al., 1976), or to impede cerebral venous return (Kowada et al., 1968). However, systemic hypotension can result in damage to heart, kidney, and other vital organs and thus is an undesirable complicating factor of studies of ischemic brain. The present study describes a new model of GPIR induced by reversible occlusion of the bilateral internal carotid arteries (ICA) and external carotid arteries (ECA) combined with permanent ligation of bilateral VA (i.e., 6AO) in rabbits. The model is not complicated by systemic hypotension and does not impede cerebral venous return.

\section{MATERIALS AND METHODS}

Native white rabbits, 30 male and 40 female, weighing $1.6 \pm 0.2 \mathrm{~kg}$, were divided into four groups: Group A, Sham-operated; Group B, 60 min of 6AO; Group C, 120 min of bilateral ICA and ECA reperfusion after $60 \mathrm{~min}$ of $6 \mathrm{AO}$; and Group D, $120 \mathrm{~min}$ of bilateral CCA reperfusion after $60 \mathrm{~min}$ of $4 \mathrm{AO}$. Rabbits were anesthetized intravenously through an ear 


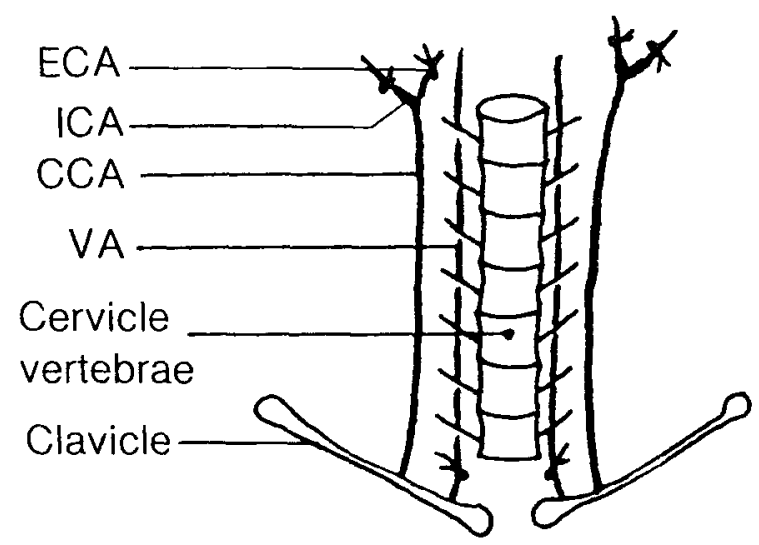

Fig. 1. Schematic representation of position of $6 \mathrm{AO}$ ICA, internal carotid artery; ECA, external carotid artery; CCA, common carotid artery.

marginal vein with $25 \%$ urethane $(1 \mathrm{~g} / \mathrm{kg})$. A stainless steel screw was mounted $3 \mathrm{~mm}$ posterior to coronal suture, and $3 \mathrm{~mm}$ right lateral to midline to record the electroencephalogram (EEG, Polygraph Nihon, Japan). A reference electrode was fixed at the ipsilateral base of the ear. Bilateral VA were isolated at supraclavicula and the side of prominent vertebra where is the beginning of VA via a ventral midline cervical incision and ligated at the beginning of VA (Fig. 1). Bilateral CCA, ICA, and ECA were isolated and a suture was loosely placed around each artery without compromising its blood flow. Femoral arteries were cannulated bilaterally and injected with $0.2 \%$ heparin, one to record the mean artery blood pressure (MABP), and the other to sample blood for $\mathrm{pH}, \mathrm{pCO} 2$, and $\mathrm{pO} 2$ (Blood gas analyzer, ABL-3 Denmark). The physiological state of the animals was assessed by measurements of rectal temperature and blood gases prior to and during the experiment. The data obtained from the 17 normal animals prior to the experiment were (average + SD): $\mathrm{PaO}_{2}, 88 \pm 2 \mathrm{mmHg} ; \mathrm{PaCO}_{2}, 31 \pm \mathrm{mmHg}$; and $\mathrm{pH}$, $7.37 \pm 0.01$. The body temperature was maintained $t 37+0.5^{\circ} \mathrm{C}$ with a heating lamp during the whole experimental period. The data were maintained in this range until the end of the experiment. The rabbits with global ischemia were in a similar physiological state. After $60 \mathrm{~min}$ of $6 \mathrm{AO}$, or $4 \mathrm{AO}$, either bilateral ICA and ECA (group C) or bilateral CCA (group D) were recirculated for $120 \mathrm{~min}$. Animals were sacrificed by an overdose of urethane and their whole brain was rapidly removed. A 4 $\mathrm{mm}$ thick slice of $8 \times 8 \mathrm{~mm}$ left parietal tissue was excised, weighed, and dried to constant wt at a temperature of $105^{\circ} \mathrm{C}$ in an electric oven. Brain water content was calculated as $(\%)=($ fresh wt - dry wt) / fresh wt $\times 00 \%$. The dried brain tissue samples were used to determine $\mathrm{K}$, 
$\mathrm{Na}, \mathrm{Ca}, \mathrm{Mg}, \mathrm{Fe}$, and $\mathrm{Zn}$ by atomic absorption spectrophotometry (HITACHI-180-70). The metabolic product of lipid peroxide (LPO) and malondialdehyde (MDA) in brain tissues was determined with thiobarbituric acid (TBA) (Yoshida et al., 1980). The activity of superoxide dismutase (SOD) was determined by the method of autoxidation of pyrogallol (Marklund and Marklund, 1974). An estimate of the effect of $6 \mathrm{AO}$ on brain perfusion was made in four other rabbits by injection into the ascending aorta of $30 \mathrm{~mL}$ normal saline containing 1\% Evans blue at pressure $120 \pm 10 \mathrm{mmHg}$. A craniotomy was immediately performed and the whole brain was removed to reveal the distribution of dye.

\section{RESULTS}

\section{Survival of Rabbits}

In $6 \mathrm{AO}$ group, 26 of 38 rabbits (68\%) survived and they were sacrificed at $120 \mathrm{~min}$ after reperfusion. In the $4 \mathrm{AO}$ group, 12 of 22 rabbits $(54 \%)$ survived and they were sacrificed at $120 \mathrm{~min}$ after reperfusion. But this difference was not statistically significant. All deaths occurred during the early period of ischemia and arrest of their respiratory occurred prior to arrest of their heart.

\section{Mean Artery Blood Pressure}

The MABP increased $18 \pm 14 \mathrm{mmHg}$ in average in group $\mathrm{B}, 15 \pm 11$ $\mathrm{mmHg}$ in average in group $\mathrm{C}$, and $24 \pm 5 \mathrm{mmHg}(p<0.05)$ in group D during 5 min of ischemia. The increase of MABP was the most remarkable in group $\mathrm{D}$. The decrease of MABP was more in group D (average decreased $37 \pm 21 \mathrm{mmHg}$ ) than in group $\mathrm{C}$ (average decreased $16 \pm 14$ $\mathrm{mmHg}$ ) at $5 \mathrm{~min}$ after reperfusion, $p<0.01$ (Table 1; Fig. 2).

\section{EEG Activity}

Table 2 shows that the EEG activity was severely depressed in all animals of group $\mathrm{B}(6 \mathrm{AO})$ and $\mathrm{C}(6 \mathrm{AO}+$ reperfusion) and 9 of 10 in group D (4AO + reperfusion) during $60 \mathrm{~min}$ ischemia. The EEG depression was more severe in group $C$ than in group D within $120 \mathrm{~min}$ reperfusion (Table 2; Fig. 3).

\section{Water Content}

The average water content of brain samples was $78.28 \pm 0.59 \%$, $78.96 \pm 0.79 \%, 80.33 \pm 1.20 \%$, and $79.42 \pm 1.29 \%$ in groups $\mathrm{A}, \mathrm{B}, \mathrm{C}$, and $\mathrm{D}$ respectively (Fig. 4). The water content was highest in group $\mathrm{C}$ $(p<0.01)$. 
Table 1

The Changes of MABP During Ischemia and Reperfusion

\begin{tabular}{|c|c|c|c|c|c|c|c|c|}
\hline \multirow{2}{*}{ Groups } & \multicolumn{4}{|c|}{ Ischemia (min.) } & & \multicolumn{3}{|c|}{ Reperfusion (min.) } \\
\hline & 0 & 5 & & 60 & & 5 & 60 & 120 \\
\hline$A(n=11)$ & $104 \pm 8$ & $104 \pm$ & 8 & $98 \pm$ & 9 & $98 \pm 9$ & $89 \pm 14$ & $84 \pm 14$ \\
\hline$B(n=12)$ & $101 \pm 8$ & $119 \pm$ & 14 & $81 \pm$ & 32 & & & \\
\hline$C(n=12)$ & $97 \pm 9$ & $112 \pm$ & $\mathbf{9}$ & $91 \pm$ & 12 & $75 \pm 13$ & $73 \pm 15$ & $61 \pm 15$ \\
\hline$D(n=10)$ & $102 \pm 10$ & $125 \pm$ & 15 & 107 & \pm 16 & $70 \pm 18$ & $68 \pm 11$ & $61 \pm 15$ \\
\hline
\end{tabular}

Values are $\mathrm{mmHg}$, mean $\pm \mathrm{SD}$. Numbers of animals are given in parentheses.

${ }^{a}$ Statistically different from $5 \mathrm{~min}$ of ischemia: $\mathrm{p}<0.05$.

"Statistically different from $60 \mathrm{~min}$ of ischemia: $p<0.05$.

'Statistically different from the decrease of BP $5 \mathrm{~min}$ after reperfusion between group $C$ and group $D$.

(by two-tailed Student's $t$-test and with Bonferroni modification)
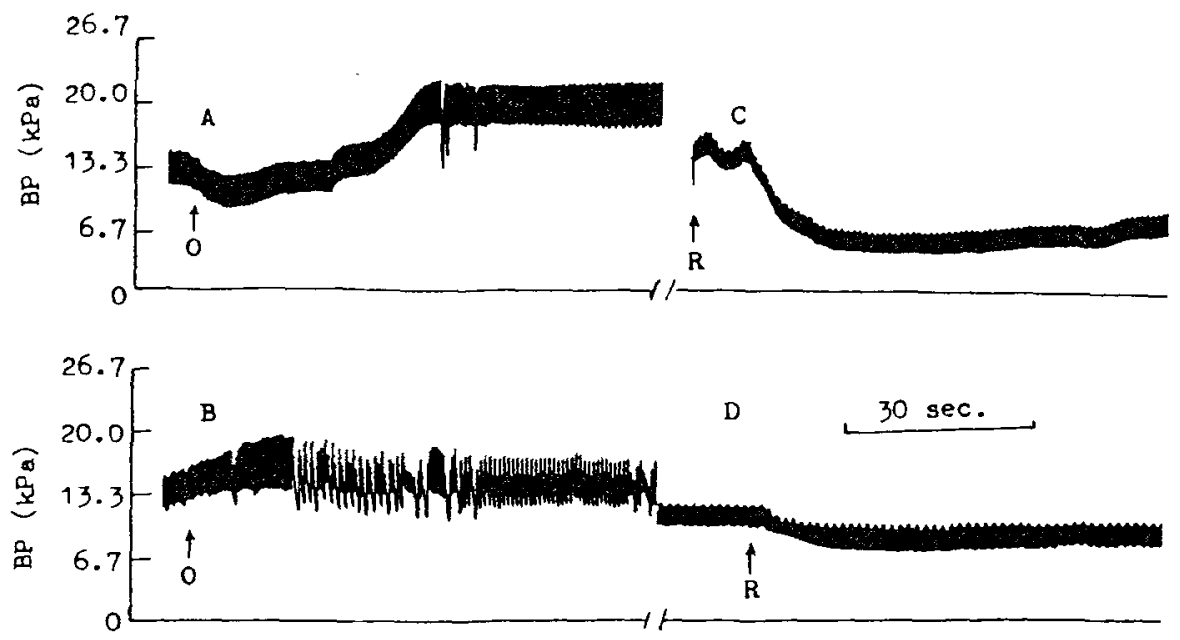

Fig. 2. The rise in blood pressure after $4 \mathrm{AO}(\mathrm{A})$ was greater than after $6 \mathrm{AO}(\mathrm{B})$. Conversely, the fall in blood pressure after bilateral CCA release $(C)$ was greater reperfusion with bilateral ICA and bilateral ECA release (D). O: occlusion; $R$ : release.

\section{Estimation of Brain Perfusion}

Injection of $1 \%$ Evans blue dye into the ascending aorta revealed well-perfused areas of the whole brain to be stained dark blue in the control (no occlusion), bilateral VA, or bilateral CCA occlusion animals. Although $6 \mathrm{AO}$ resulted in a marked decrease in perfusion of the cerebral 
Table 2

The Changes of EEG Activity During Brain Ischemia and Reperfusion in Rabbits

\begin{tabular}{|c|c|c|c|c|c|c|c|}
\hline \multirow{2}{*}{ Scale } & \multicolumn{3}{|c|}{ (60 min ischemia) } & \multirow{2}{*}{$\begin{array}{l}\text { Groups } \\
\frac{D}{D}\end{array}$} & (120 min & \multicolumn{2}{|c|}{ reperfusion) } \\
\hline & A & B & $\mathrm{C}$ & & A & C & D \\
\hline $\begin{array}{l}\text { I } \\
\text { I I } \\
\text { I I I } \\
\text { I V }\end{array}$ & $\begin{array}{r}0 \\
0 \\
0 \\
11\end{array}$ & $\begin{array}{r}10 \\
2 \\
0 \\
0\end{array}$ & $\begin{array}{r}11 \\
1 \\
0 \\
0\end{array}$ & $\begin{array}{l}8 \\
1 \\
0 \\
1\end{array}$ & $\begin{array}{l}0 \\
0 \\
2 \\
9\end{array}$ & $\begin{array}{l}8 \\
3 \\
1 \\
0\end{array}$ & $\begin{array}{l}4 \\
3 \\
3 \\
0\end{array}$ \\
\hline $\begin{array}{l}\text { H valu } \\
\text { p val }\end{array}$ & $\begin{array}{l}\text { ue* } \\
\text { ue }\end{array}$ & & & & & $\begin{array}{l}20.85 \\
<0.01\end{array}$ & \\
\hline
\end{tabular}

Note: Scale I: The voltage was less than $25 \%$ initial level or isoelectric; Scale II: $50-25 \%$ initial level; Scale III: $75-50 \%$ initial level; Scale IV: more than $75 \%$ initial level or no observed change.

${ }^{*}$ Kruskal Wallis test.

hemispheres, it did not produce a complete ischemia because of collateral supply (Fig. 5).

\section{Lipid Peroxide (LPO), Superoxide Dismutase (SOD), and Ionic Content}

Table 3 shows that the difference of LPO was not significant from group to group. The lowest activity of SOD occurred in group $\mathrm{C}$, and was significant when compared with groups $\mathrm{A}$ and $\mathrm{B}(p<0.01)$. Moreover, there was a negative correlation between the changes in activity of SOD and water content of brain, but there was no correlation between LPO and water content of brain (Fig. 6).

The detection of ionic content revealed changes of $\mathrm{K}, \mathrm{Na}, \mathrm{Mg}$, and $\mathrm{Zn}$ in group $\mathrm{C}$ as either significant $(p<0.05)$ or highly significant $(p<$ 0.01 ), when compared with either group A or B (Table 3). There was a positive correlation between $\mathrm{Na}$ and water content, and there was a negative correlation between water content and $\mathrm{K}, \mathrm{Ca}, \mathrm{Mg}$, and $\mathrm{Zn}$ (Fig. 6). No significant changes were observed on $\mathrm{K}, \mathrm{Na}, \mathrm{Ca}, \mathrm{Mg}$, Fe, or $\mathrm{Zn}$ in group B (ischemia only).

\section{DISCUSSION}

The previous methods that produced global ischemia were usually used by bilateral CCA occlusion. The method of bilateral CCA could result in the rise of systemic blood pressure due to the reflex of carotid sinuses. Thus the hypertension could open the collateral circulation 
0

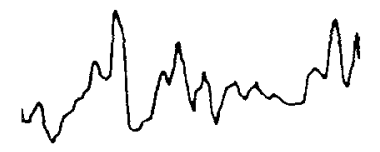

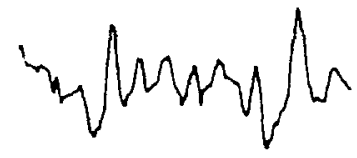

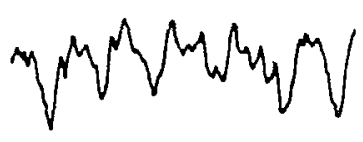
$50 \mu \mathrm{VL}$

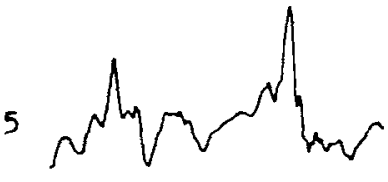
2 secood

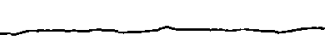

$I-5$ min

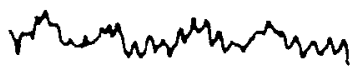

$I-5 \ln$

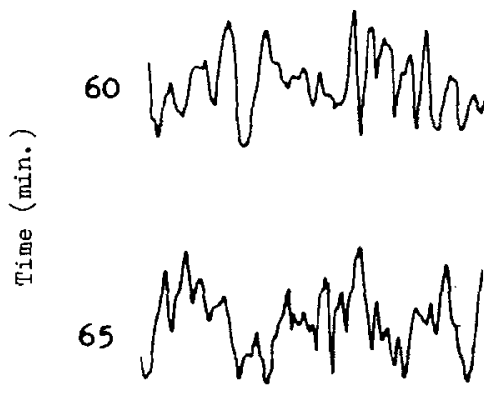

$R P-5 m 1 n$
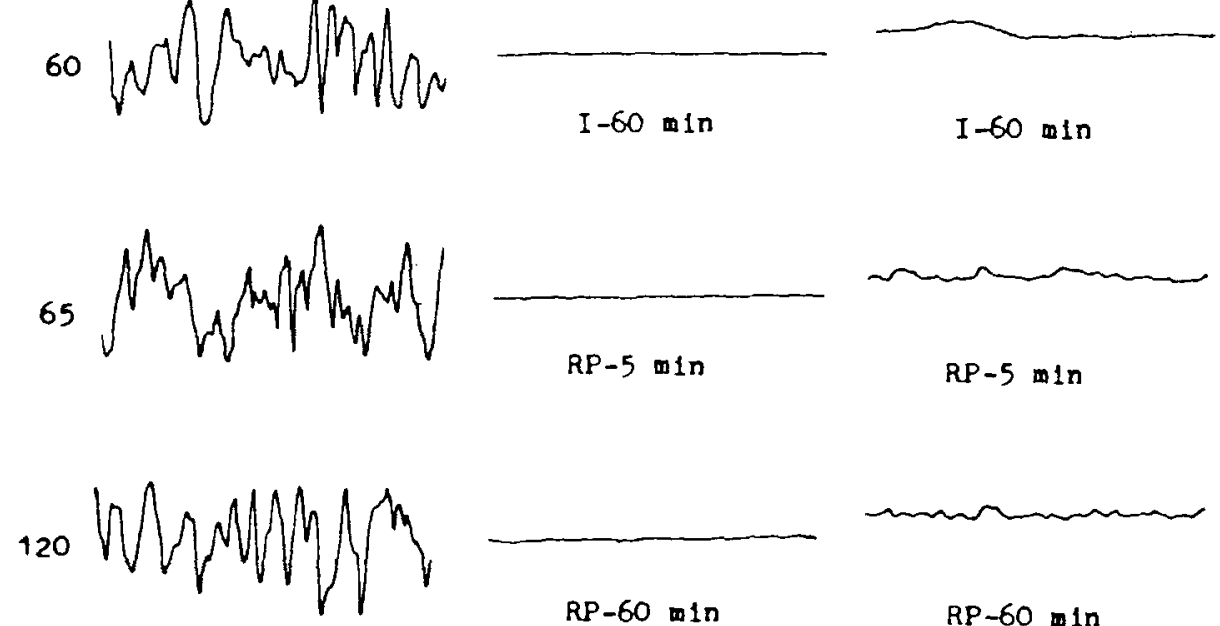

$$
\text { I }-60 \mathrm{~m} \ln
$$

$I-60 \mathrm{~min}$

$R P-60 \mathrm{~min}$

180

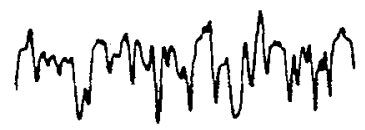

Group A

$$
\text { RP-12001n }
$$

Group C
$R P-60 \mathrm{~min}$
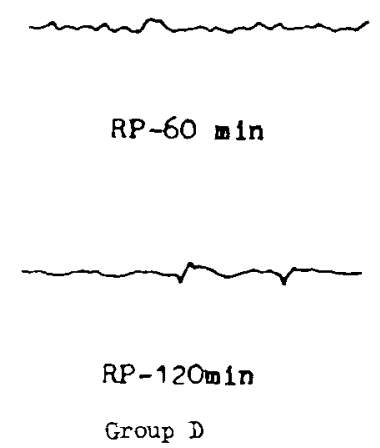

Fig. 3. The time course of EEG activity comparing group A (control), with group $C(6 \mathrm{AO})$ and group $D(4 \mathrm{AO})$. Depression of EEG activity is more severe in group $C$ than group $D$ during ischemia (I) and reperfusion (RP).

between anterior spinal arteries and cerebral arteries (Hossmann and Zimmermann, 1979). On the other hand, the drop of pressure of carotid sinus baroreceptor itself also could result in the compensable increase of cerebral blood flow (Ponte and Purves, 1974). So, those methods that resulted in global ischemia have to associate with a systemic hypotension induced by bleeding ( $\mathrm{Li}$ et al., 1987) or drugs (Boulu et al., 1981; Kolata,1979; Mchedlishvili et al., 1976), even to prevent venous drainage 


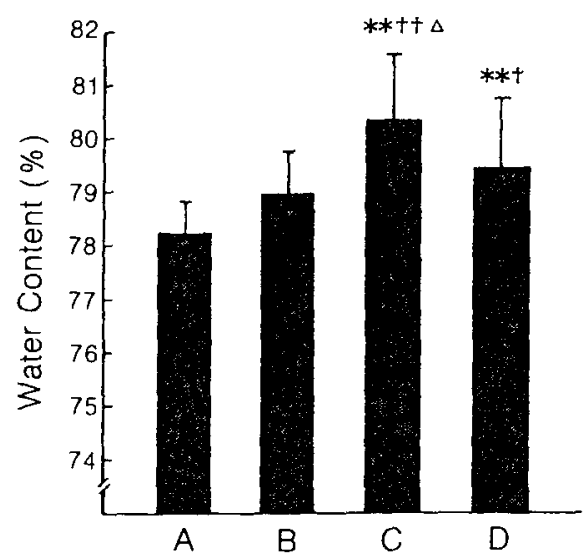

Fig. 4. The water content of brain tissue (mean $\pm S D$ ). A. Shamoperated, $n=16 ; \mathrm{B}$. $60 \mathrm{~min}$ of $6 \mathrm{AO}, n$ $=17 ; \mathrm{C} .120 \mathrm{~min}$ of reperfusion after $60 \mathrm{~min}$ of $6 \mathrm{AO} n=16$; D. $120 \mathrm{~min}$ of reperfusion after $60 \mathrm{~min}$ of $4 \mathrm{AO}, n=$ 10. ${ }^{* *}$ compared with group A $p<$ 0.01 ; + compared with group B $p<$ 0.05 , t+ $p<0.01 ; \Delta$ compared with group $\mathrm{D} p<0.01$.

from the head (Kowada et al., 1968). However, sustained systemic hypotension could result in the damage to heart, kidney, and other vital organs. A significant feature of the new method described is avoidance of the pressure of bilateral carotid sinuses dropping abruptly, thus maintaining normal tension in the bilateral carotid sinuses and normal systemic blood pressure. So, the new model might avoid the compensable increase of cerebral blood flow. Consequently, it did not have to make a systemic hypotension, thus avoided the damage to vital organs induced by hypotension.

Our data on survival rate $(68 \%)$ in $6 \mathrm{AO}$ group after cerebral reperfusion are compatible with the results reported by Kolata $(70 \%$, Kolata, 1979), but are remarkably higher than results reported by others using rabbits $(40 \%$, Kowada et al., 1968) or dogs (more than 40\%, Jackson and Dole, 1979). We consider the survival rate might be increased in our model if artificial ventilator would be used in each animal, because our data showed that in all deaths arrest of their respiratory was prior to arrest of their heart.

The depression of EEG activity is an important feature of brain ischemia, and correlates strongly with the degree of brain ischemia. The changes of EEG did not happen until the regional cerebral blood flow (rCBF) decreased to $20 \mathrm{~mL} \cdot 100 \mathrm{~g}^{-1} \cdot \mathrm{min}^{-1}$; and the EEG did not become 

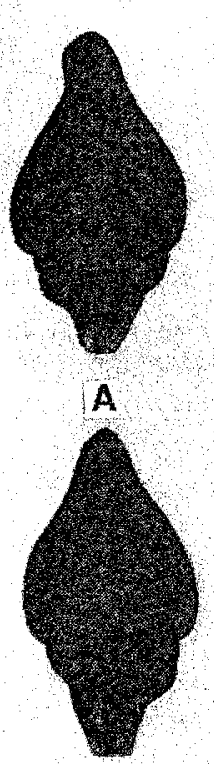
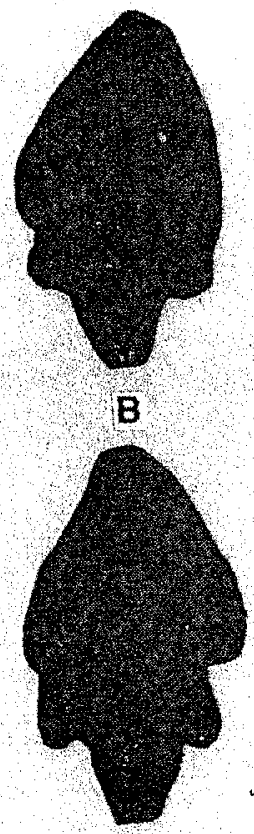

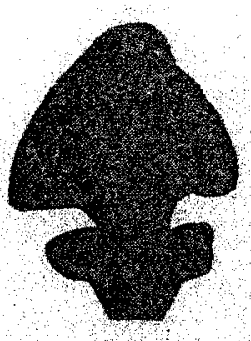

$\mathrm{C}$

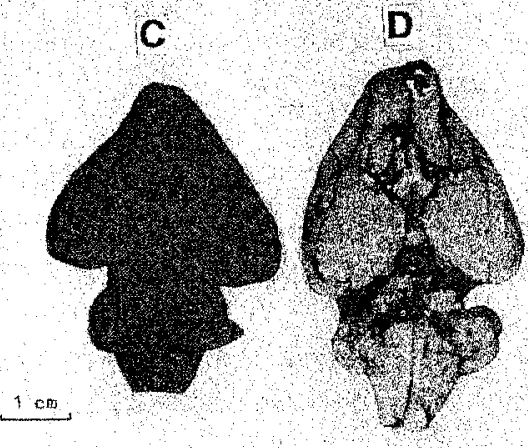

Fig. 5. Dorsal and ventral views of whole brains in rabbits injected via the ascending aorta with $1 \%$ Evans blue. A. control; B. bilateral VA occlusion; C. bilateral CCA occlusion, whole brains were well perfused. D. 6AO; slightly perfused with dye in cerebellum, basilar artery, and circle of Willis.

Table 3

LPO, SOD, and Ionic Content in Brain Tissue of Ischemic Rabbit Brain

\begin{tabular}{|c|c|c|c|c|c|c|c|c|c|}
\hline Group & $\mathbf{N}$ & LPO & SOD & $\mathbf{K}$ & $\mathrm{Na}$ & $\mathrm{Ca}$ & $\mathbf{M g}$ & $\mathrm{Fe}$ & $\mathrm{Zn}$ \\
\hline $\bar{A}$ & 6 & $\begin{array}{l}225 \\
\pm 40\end{array}$ & $\begin{array}{r}469 \\
\pm 28\end{array}$ & $\begin{array}{l}94.5 \\
\pm 3.3\end{array}$ & $\begin{array}{l}52.1 \\
\pm 2.3\end{array}$ & $\begin{array}{r}1.32 \\
\pm .28\end{array}$ & $\begin{array}{r}6.69 \\
\pm .24\end{array}$ & $\begin{array}{r}309 \\
\pm 35\end{array}$ & $\begin{array}{l}214 \\
\pm 11\end{array}$ \\
\hline B & 7 & $\begin{array}{r}216 \\
\pm 57\end{array}$ & $\begin{array}{r}431 \\
\pm 55\end{array}$ & $\begin{array}{l}87.8 \\
\pm 5.1\end{array}$ & $\begin{array}{l}52.7 \\
\pm 5.9\end{array}$ & $\begin{array}{l}1.22 \\
\pm .07\end{array}$ & $\begin{array}{l}6.53 \\
\pm .42\end{array}$ & $\begin{array}{l}300 \\
\pm 11\end{array}$ & $\begin{array}{r}196 \\
\pm 7\end{array}$ \\
\hline C & 6 & $\begin{array}{l}227 \\
\pm 38\end{array}$ & $\begin{array}{l}35^{a, c} \\
\mathbf{3} 62^{2}\end{array}$ & $\begin{array}{r}72.1^{a, c} \\
\pm 15.8\end{array}$ & $\begin{array}{l}63.0^{b, c} \\
\pm 9.2\end{array}$ & $\begin{array}{l}1.50 \\
\pm .42\end{array}$ & 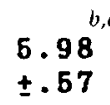 & $\begin{array}{r}359 \\
\pm 9\end{array}$ & $\begin{array}{l}192^{a} \\
\pm 15\end{array}$ \\
\hline
\end{tabular}

Values are $\mu / g$ dry wt (SOD), nmol/g dry wt (LPO, Fe, $\mathrm{Zn}$ ), or $\mu \mathrm{mol} / \mathrm{g}$ dry wt (K, $\mathrm{Na}, \mathrm{Ca}, \mathrm{Mg}$ ), mean $\pm \mathrm{SD}$.

"Statistically different from group A: $\mathrm{p}<0.01$.

${ }^{b}$ Statistically different from group A: $p<0.05$.

'Statistically different from group $B: p<0.01$.

${ }^{d}$ Statistically different from group B: $p<0.05$.

(by two-tailed Student's $t$-test and with Bonferroni modification) 

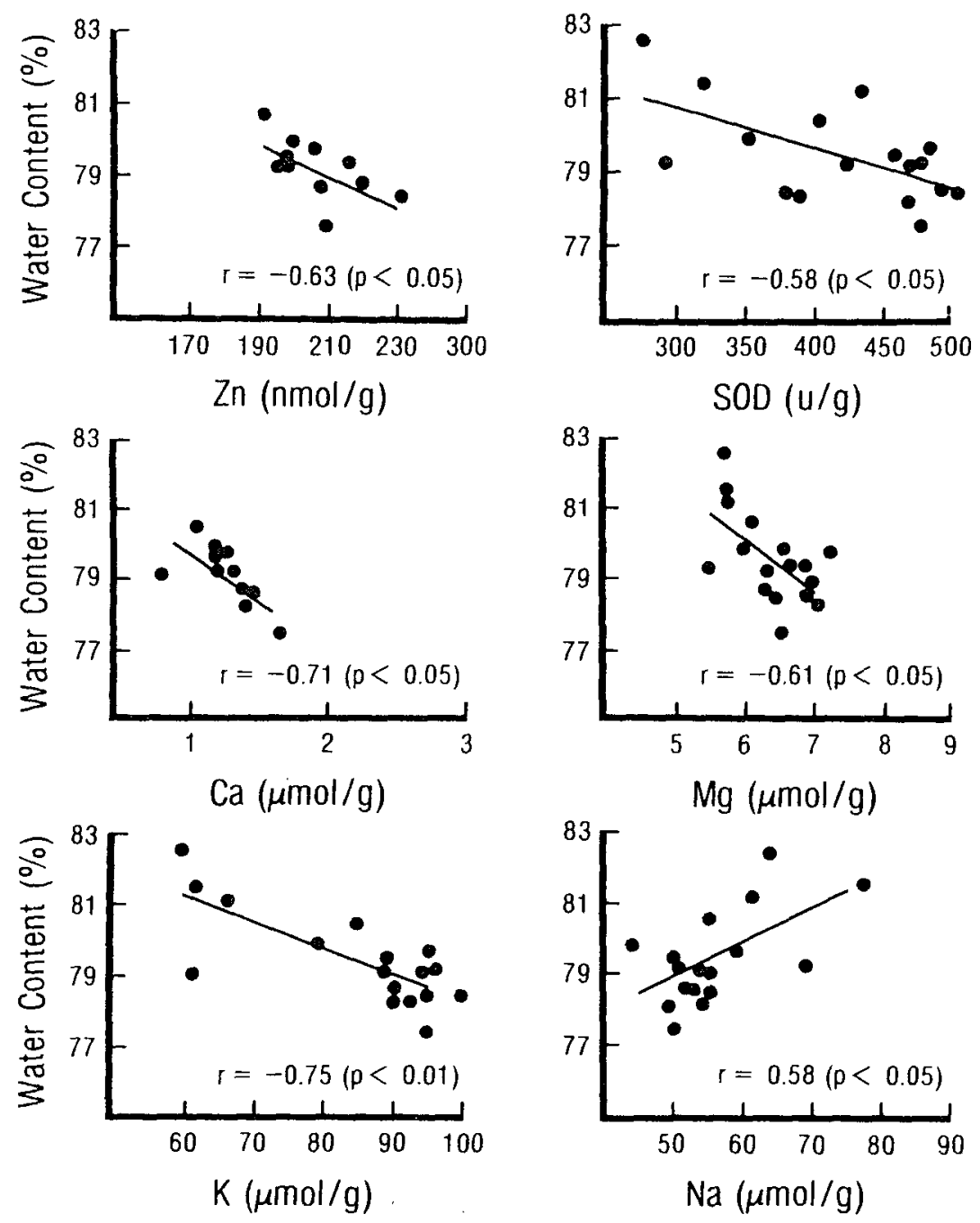

Fig. 6. The correlation between water content and the activity of SOD, and ions during ischemia and reperfusion in brain tissue of rabbits. Each point came from the same sample of group A.B.C. $n=17$ in $\mathrm{K}, \mathrm{Na}, \mathrm{Mg}$, and SOD; $n=11$ in $\mathrm{Ca}$, and $\mathrm{Zn}$.

isoelectric until $\mathrm{rCBF}$ decreased to $15-18 \mathrm{~mL} \cdot 100 \mathrm{~g}^{-1} \cdot \mathrm{min}^{-1}$ (Rehncrona, 1986; Sundt et al., 1974; Trojaborg and Boysen, 1973). This model demonstrated that the activities of EEG were depressed markedly in all animals with $6 \mathrm{AO}$. It suggested that $\mathrm{rCBF}$ be decreased strongly during $6 \mathrm{AO}$.

Brain edema is another important feature of brain ischemia (Klatzo et al., 1984). The changes of water content of brain also correlate strongly with rCBF. Iannotti and Hoff (1983) and Crockard et al. (1980) measured the relationship between brain edema and rCBF in their model with the gerbil. Their results showed that brain edema did not occur during zero 
rCBF (e.g., "no flow no edema") and the most severe brain edema occurred with rCBF less than $10 \mathrm{~mL} \cdot 100 \mathrm{~g}^{-1} \cdot \mathrm{min}^{-1}$, and that it was not easily reabsorbed after reperfusion. Brain edema was mild during rCBF values in the range of $10-14 \mathrm{~mL} \cdot 100 \mathrm{~g}^{-1} \cdot \mathrm{min}^{-1}$, and it was easily reabsorbed after reperfusion. The water content of brain tissue was increased markedly in our $6 \mathrm{AO}$ model $(p<0.01)$. It also suggested that the $\mathrm{rCBF}$ be decreased strongly in the $6 \mathrm{AO}$ model.

It is not yet well understood why brain edema can sometimes deteriorate rather than ameliorate during the reperfusion of ischemic brain tissue. It has been thought that the accumulation of metabolic substances and cellular energy exhaustion might be responsible for the formation of brain edema in the ischemic period (Iannotti, 1983; Siesjo and Wieloch, 1985), but during reperfusion, free radical release might be responsible. (Braughler and Hall, 1989; Hall and Braughler, 1989; McCord, 1988; Yang, 1987). Yoshida (1980) and Yamamoto et al. (1983) reported that the metabolic product of LPO (MDA) was increased during cerebral reperfusion in gerbils or rats. Our results failed to show that the increasing of MDA at 120 min of reperfusion; however, the activity of SOD was decreased markedly, and the decrease correlated negatively with water content of brain. The decrease of activity of SOD might be due to increased SOD consumption caused by an excess of superoxide free radicals and brain tissue anoxia.

With regard to ionic homeostasis during brain reperfusion, Kumar et al. (1987) studied the changes of $\mathrm{K}, \mathrm{Na}, \mathrm{Ca}, \mathrm{Mg}$, and Fe levels of the brain tissue during resuscitation after $15 \mathrm{~min}$ of cardiac arrest, and found that $\mathrm{Na}$ and $\mathrm{Ca}$ were increased, $\mathrm{K}$ decreased, but no significant changes occurred in levels of $\mathrm{Mg}$ and Fe levels. Our results showed that the changes of $\mathrm{Na}$ and $\mathrm{K}$ were similar to Kumar's, $\mathrm{Mg}$ and $\mathrm{Zn}$ were decreased with statistically significant, and the changes were not statistically significant in $\mathrm{Ca}$ and $\mathrm{Fe}$.

\section{ACKNOWLEDGMENTS}

We are indebted for excellent technical assistance provided by Mr. P. Zou, Mrs. S.A. Zhang, Mr. D.C. Liu, Mr. S. Tan, and Mr. Y.G. Zhou of Hunan Medical University; and for the assistance of Mr. Michael McHugh and Professor Hanna M. Pappius of Montreal Neurological Institute in preparation of the manuscript.

The project was supported by National Natural Science Foundation of China and The Public Health Department of Human Province.

\section{REFERENCES}

Aguilar J. A. (1963) Cerebral vascular insufficiency in rabbits after baselar artery ligation. J. Neuropath. Exp. Neurol. 22, 617-628. 
Boulu R. G., Gueniau C., Plotkine M., and Sofeir M. (1981) Recovery from global cerebral ischemia in rabbits: Influence of indomethacin. Eur. Neurol . 20, 230234.

Branston N. M., Bell B. A., Hunstook A., and Symon L. (1980) Time and flow as factors in the formation of postischemic edema in primate cortex, in $A d$ vances in Neurology. Vol. 28. Brain Edema. (Cervos-Navarro J., et al. eds.), pp. 291-298, Raven Press, New York.

Braughler J. M. and Hall E. D. (1989) Central nervous system trauma and stroke, I. Biochemical considerations for oxygen radical formation and lipid peroxidation. Free Radical Biology 6, 289-301.

Crockard A., Iannotti F., Hunstock A. T., Smith R. D., Harris R. F., and Sumon L. (1980) Cerebral blood flow and edema following carotid occlusion in the gerbil. Stroke 11, 494-498.

Gu Z. Z. (1983) Cerebral circulation and clinic. p. 20, Scientific and Technological Publishing House, Shanghai.

Hall E. D. and Braughler J. M. (1989) Central nervous system trauma and stroke, II. Physiological and pharmacological evidence for involvement of oxygen radicals and lipid peroxidation. Free Radical Biology 6, 303-313.

Hossmann K-A. and Zimmermann V. (1979) Resuscitation of the monkey brain after 1 hour complete ischemia. I. Physiological and morphological observations. Brain Res. 81, 59-74.

Iannotti F. and Hoff J. (1983) Ischemic brain edema with and without reperfusion: An experimental study in gerbils. Stroke 14, 562-567.

Jackson D. L. and Dole W. P. (1979) Total cerebral ischemia: A new model system for the study of postcardiac arrest brain damage. Stroke 10, 38-43.

Klatzo I., Suzuki R., Orzi F., Schuier F., and Nitsch C. (1984) Pathomechanisms of ischemic brain edema, in Recent Progress in the Study and Therapy of Brain Edema (Go K. G. and Baethman A., eds.), pp. 1-10, Plenum Press, New York and London.

Kolata R. J. (1979) Survival of rabbits after prolonged cerebral ischemia. Stroke 10, 272-277.

Kowada M., Ames A., Majno G., and Wright R. L. (1968) Cerebral ischemia I. An improved experimental method for study; cardiovascular effects and demonstration of an early vascular lesion in the rabbit. J. Neurosurg. 28, 150175.

Kumar K., Goosmann M., Krause G. S., Nayini N. R., Estrada R., Hoehner T. J., White B. C., and Koestner A. (1987) Ultrastructural and ionic studies in global ischemic dog brain. Acta. Neuropathol. (Berl), 73, 393-399.

Li Y. Y., Wang A. C., and Li L. X. (1987) Studies on acute incomplete cerebral ischemic and reperfusion damages in rabbits. Chinese J. Pathophysiol. 3, 9397.

Marklund S. and Marklund G. (1974) Involvement of the superoxide anion radical in the autoxidation of pyrogallol and a convenient assay for superoxide dismutase. Eur. J. Biochem. 47, 469-474.

McCord J. M. (1988) Free radicals and myocardial ischemia: Overview and outlook. Free Radical Biology and Medicine 4, 9-14.

Mchedlishvili G., Kapuscinski A., and Nikolaishvili L. (1976) Mechanisms of postischemic brain edema: Contribution of circulatory factors. Stroke 7, 410415. 
Paschen W., Hossmann K. A., and Ven den Kerekhoff W. (1983) Regional assessment of energy-producing metabolism following prolonged complete ischemia of cat brain. J. Cereb. Blood Flow Metab. 3, 321-329.

Ponte J. and Purves M. J. (1974) The role of the carotid body chemoreceptors and carotid sinus baroreceptors in the control of cerebral blood vessels. J. Physiol. $237,315-340$.

Pulsinelli W. A. and Brierley J. B. (1979) A new model of bilateral hemispheric ischemia in the unenesthetized rat. Stroke 10, 267-272.

Rehncrona S. (1986) Molecular mechanisms for ischemic brain damage and aspects of protection. Acta Neurochirugica. (Suppl.) 36, 125-128.

Siesjo B. K. and Wieloch T. (1985) Cerebral metabolism in ischemia: Neurochemical basis for therapy. Br. J. Anaesth. 57, 47-62.

Sundt T. M., Sharbrough F. W. Anderson R. E., and Michenfelder J. D. (1974) Cerebral blood flow measurements and electroencephalograms during carotid endarterectomy. J. Neurosurg. 41, 310-320.

Todd N. V., Picozzi P., Crockard H. A., and Russell R. R. (1986) Reperfusion after cerebral ischemia: Influence of duration of ischemia. Stroke 17, 460-466.

Trojaborg W. and Boysen G. (1973) Relation between EEG, regional blood flow and internal carotid artery pressure during carotid endarterectomy. EEG. Clin. Neurophysiol. 34, 61-69.

Yamamoto M., Shim T., Uozumi T., Sogabe T., Yamada K., and Kawasaki T. (1983) A possible role of lipid peroxidation in cellular damages caused by cerebral ischemia and the protective effect of $\alpha$-tocopherol administration. Stroke 14, 977-982.

Yang Y. J. (1987) Free radical and brain edema, in Advances in Pathophysiology III. (Pan S.C. and Luo Z. Y., eds.), pp. 84-96. People's Health Publishing House, Beijing.

Yoshida S., Inoh S., Asano T., Sano K., Kubota M., Shimazaki H., and Ueta N. (1980) Effect of transient ischemia on free fatty acids and phospholipids in the gerbil brain. I. Neurosurg. 53, 323-331. 